\title{
Edible Protein Production by Filamentous Fungi using Starch Plant Wastewater
}

\author{
Pedro F. Souza Filho ${ }^{1} \cdot$ Akram Zamani $^{1} \cdot$ Mohammad J. Taherzadeh ${ }^{1}$
}

Received: 18 January 2018 / Accepted: 5 March 2018

(c) The Author(s) 2018. This article is an open access publication

\begin{abstract}
The process to obtain starch from wheat requires high amounts of water, consequently generating large amounts of wastewater with very high environmental loading. This wastewater is traditionally sent to treatment facilities. This paper introduces an alternative method, where the wastewater of a wheat-starch plant is treated by edible filamentous fungi (Aspergillus oryzae and Rhizopus oryzae) to obtain a protein-rich biomass to be used as e.g. animal feed. The wastewater was taken from the clarified liquid of the first and second decanter (ED1 and ED2, respectively) and from the solid-rich stream (SS), whose carbohydrate and nitrogen concentrations ranged between 15 and 90 and $1.25-1.40 \mathrm{~g} / \mathrm{L}$, respectively. A. oryzae showed better performance than $R$. oryzae, removing more than $80 \%$ of COD after 3 days for ED1 and ED2 streams. Additionally, 12 g/L of dry biomass with protein content close to $35 \%(\mathrm{w} / \mathrm{w}$ ) was collected, demonstrating the potential of filamentous fungi to be used in wastewater valorization. High content of fermentable solids in the SS sample led to high production of ethanol $(10.91 \mathrm{~g} / \mathrm{L})$, which can be recovered and contribute to the economics of the process.
\end{abstract}

Keywords Filamentous fungi $\cdot$ Wastewater treatment $\cdot$ Bioethanol $\cdot$ Fungal biomass

\section{Introduction}

Wheat is one of the most important crops in human diet. Globally, wheat supplies more protein than poultry, pig, and bovine meat together [1]. The European Union (EU) is the most important producer of wheat in the world, accounting for over $20 \%$ of the global production [2]. According to the European starch manufacture, wheat is the most processed crop, accounting for $35.9 \%$ of the total 23.6 million tons of crops processed annually. In 2015, wheat yielded 39.6\% of the 10.7 million tons of starch produced [3]. Starch is a naturally occurring polymer with numerous industrial applications, including food, paper, cosmetic, pharmaceutical, textile, and detergent industries [4, 5]. Several methods of starch production from wheat were reviewed by Van Der Borght et al. [6]. These methods can demand up to 1.8 parts of water per part of wheat flour [6]. This wastewater has to be treated at the end of the process, which represents an environmental challenge due to the large chemical oxygen

Pedro F. Souza Filho

pedro.ferreira_de_souza_filho@hb.se

1 Swedish Centre for Resource Recovery, University of Borås, 50190 Borås, Sweden demand (COD) of the wastewater, generally ranging between 6 and $10 \mathrm{~g} / \mathrm{L}$ [7-10].

In the EU, legislation governing emissions from industrial installations follows the "polluter pays" principle. These norms use market-based instruments so the industry takes responsibility on the external damage caused by industrial activities. Such instruments include taxes and emission trading schemes. The environmental policy requires industrial plants to be equipped with the Best Available Techniques (BAT) to reach specific emissions limit values. To do so, industries may have to implement new measures [11]. Currently, as a method to reduce the COD emissions, the suspended solids present in the wastewater are collected and sold as feed additive. Usually, the solid recovery is achieved by decantation, but this operation results in low efficiency and requires long settling times. Furthermore, the use of flocculants is not recommended since it may have adverse effects on animals [9].

In general, starch wastewater contains a significant amount of carbohydrates, protein, and nutrients. Instead of being sent to a wastewater treatment plant for microbial removal, these nutrients can be recovered either through purification processes or through the cultivation of microorganisms for the production of useful biomaterials [10]. 
Filamentous fungi, for instance, grown in industrial waste materials presented as an interesting alternative to the use of refined sugars [12]. Antibiotics, enzymes, organic acids, and ethanol are among the assortment of chemicals which can be produced by filamentous fungi. Moreover, the fungal biomass with high content of proteins and lipids is also a valuable product. It is easily harvested and can be used .g. animal feed $[12,13]$.

Among the variety of filamentous fungi, ascomycetes have been described in the literature as a group of versatile microorganisms which can grow using different substrates, including wheat straw and wheat bran. Aspergillus oryzae is an example of ascomycetes, and one of the most studied fungal species for industrial applications [12]. The ability to grow on low or negative cost substrates, such as agro-wastes and residues has also drawn attention to the zygomycetes [14]. Rhizopus oryzae, a zygomycete fungus, can potentially replace fish feed, as reported in the literature [15]. Jin et al. [16] investigated different filamentous fungi, including Fusarium spp., Trichoderma spp., Aspergillus spp., and Rhizopus spp., to produce biomass and clean water from the effluent of a wheat- and corn-starch plant, obtaining a removal of up to $92 \%$ of the initial COD.

The goal of the present paper is to use the wastewater (including the suspended solids) of a wheat-starch plant as a substrate for filamentous fungi and collect the protein-rich biomass. This effluent has not been investigated before for the cultivation of $A$. oryzae and $R$. oryzae. Initially, three streams from the wheat-starch wastewater treatment plant (Fig. 1) were characterized in terms of composition of carbohydrates and nitrogen; the side streams were then tested as media for the growth of the two microorganisms. Addition of enzymes (cellulase and amylase) to help the digestion of complex carbohydrates was also investigated. The protein content of the collected biomass and the COD of the residual liquid were determined and presented.

\section{Materials and Methods}

\section{Industrial Wastewater}

Wastewater from wheat-starch production was kindly provided by Interstarch GmbH (Elsteraue, Germany). All the wastewater from the starch plant is sent to two decanters in series, before sending the clarified liquid to the municipal wastewater plant. A block flow diagram is presented in Fig. 1. Three samples were used in this study: ED1, collected after the first decanter; ED2, collected after the second decanter; and SS, the mixture of the solid-rich streams of both decanters.

\section{Microorganisms}

Rhizopus oryzae CCUG 28958 (Culture Collection of the University of Gothenburg, Sweden) and Aspergillus oryzae var. oryzae CBS 819.72 (Centraalbureau voor Schimmelcultures, Utrecht, The Netherlands) were grown on a solid PDA (Potato Dextrose Agar) medium in 25-mL glass bottles for 5 days at $30{ }^{\circ} \mathrm{C}$ without agitation. After the mycelial growth and sporulation, the slants were maintained at $5{ }^{\circ} \mathrm{C}$ (up to 30 days) until use. Inoculation was started by pouring $12 \mathrm{~mL}$ of sterile water on each slant. The slants were then closed, and manually agitated to release the spores. The obtained spore suspension was used to inoculate the liquid medium to reach a concentration between $2 \times 10^{5}$ and $5 \times 10^{5}$ spores/ $\mathrm{mL}$ in the final medium.

\section{Analytical Methods}

Total solids content of the wastewater samples was determined by drying $10 \mathrm{~mL}$ of the homogenized samples at $105{ }^{\circ} \mathrm{C}$ until constant weight. To determine the ash content, the solids were placed in a muffle furnace (Gallenkamp, UK) at $575{ }^{\circ} \mathrm{C}$ for $5 \mathrm{~h}$. Thereafter, the fraction of suspended solids was determined by centrifuging at $3000 \times g$ for $10 \mathrm{~min}$ and drying the obtained solid at $105^{\circ} \mathrm{C}$ until constant weight. The difference between suspended and total solids yields the amount of soluble solids.
Fig. 1 Block flow diagram (BFD) representing the preliminary wastewater treatment plant and the streams in the wheatstarch facility

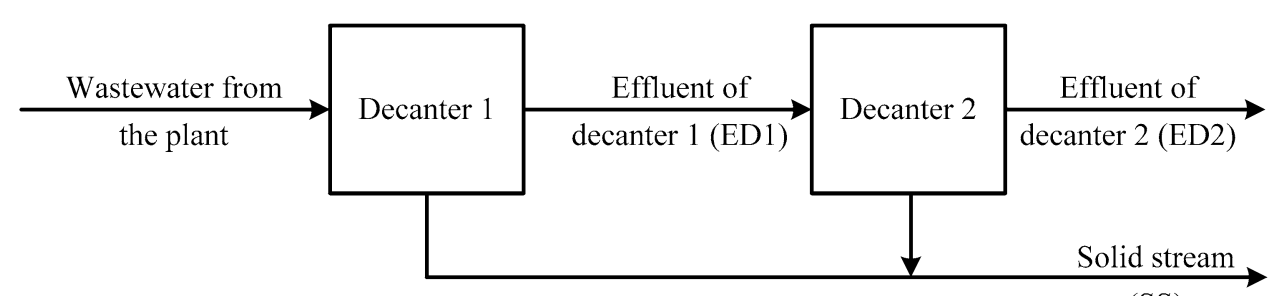

(SS) 
Acetic acid, lactic acid, glycerol, ethanol, glucose, and other sugars were analyzed using a high-performance liquid chromatography (HPLC) by a hydrogen-ion based ionexchange column (Aminex HPX-87H, Bio-Rad, Hercules, CA, USA) at $60{ }^{\circ} \mathrm{C}$, using $0.6 \mathrm{~mL} / \mathrm{min}$ of $0.5 \mathrm{mM} \mathrm{H}_{2} \mathrm{SO}_{4}$ solution as the eluent. The NREL analytical procedure [17] was used to determine carbohydrates and lignin in the suspended solids of the waste streams. The liquid containing the soluble solids was analyzed in terms of carbohydrates and their degradation products, using another NREL procedure [18]. A HPLC lead (II)-based column (Aminex HPX-87P, Bio-Rad) operating at $85{ }^{\circ} \mathrm{C}$ and $0.6 \mathrm{~mL} / \mathrm{min}$ of ultrapure water as the eluent was used to detect the sugars which were released in the NREL procedures. A refractive index detector (Waters 2414, USA) was used to identify and quantify the components.

The sucrose/D-fructose/D-glucose assay kit, the total starch assay kit, and the raffinose/D-galactose assay kit from Megazyme (Ireland) were used to obtain a soluble carbohydrate profile of the wastewater. The InKjel P digestor and the Behrotest S1 distiller (Behr Labor-Technik, Germany) were used to determine the total Kjeldahl nitrogen (TKN) content for solid and liquid samples. Protein content in the fungal biomass was estimated by multiplying the nitrogen content found in the sample by a nitrogen-to-protein factor (6.25) [19]. AQUANAL ${ }^{\mathrm{TM}}$ - professional tube test COD (1000-15,000 mg/L) (Sigma-Aldrich, USA) was used to determine the chemical oxygen demand in liquid samples. All experiments were conducted in duplicates.

\section{Fungal Cultivation}

Aspergillus oryzae and R. oryzae were cultivated in $250 \mathrm{~mL}$ baffled Erlenmeyer flasks, covered with a cotton plug, containing $50 \mathrm{~mL}$ of culture medium (the wastewater without dilution or nutritional supplementation). Sterilization of the media was carried out at $121{ }^{\circ} \mathrm{C}$ for $20 \mathrm{~min}$ before inoculation with $5 \mathrm{~mL}$ of the spore suspension at room temperature. The cultivation was carried out in a water bath shaker at $35{ }^{\circ} \mathrm{C}$ and $120 \mathrm{rpm}$. The original $\mathrm{pH}$ of the ED1 and ED2 samples was used and not adjusted during the cultivation. The SS sample was tested at the original $\mathrm{pH}$ and $\mathrm{pH}$ adjusted to 5.5 prior to cultivation. At the end of each cultivation, the produced fungal biomass was firstly collected using a kitchen sieve and then freeze dried, and weighed.

COD removal efficiency was also determined, according to Eq. 1.

$\eta_{C O D}=\frac{[C O D]_{o}-[C O D]_{f}}{[C O D]_{o}} \times 100 \%$

where $\eta_{\mathrm{COD}}$ is the percentage COD removal efficiency, $[\mathrm{COD}]_{0}$ is the initial COD concentration of the medium, and $[\mathrm{COD}]_{\mathrm{f}}$ is the COD concentration at the end of the cultivation.

Samples were taken during cultivation to monitor the consumption of sugars and production of metabolites. New tests were carried out to study the influence of the addition of enzymes on fungal cultivation. Because of the high content of starch and fibers in the streams, $0.1 \mathrm{~mL}$ of cellulase Cellic ${ }^{\circledR}$ CTec2 (94 FPU/mL, Novozymes, Denmark) and $0.1 \mathrm{~mL}$ of amyloglucosidase from Aspergillus niger (300 U/ $\mathrm{mL}$, Sigma, USA) were added to the Erlenmeyer flasks at the start of the cultivation. All the other parameters were kept as previously mentioned. All the cultivation experiments were conducted in triplicates.

\section{Statistical Analysis}

The data collected from the experiments were statistically analyzed using the software MINITAB ${ }^{\circledR}$ version 17.1.0. Analyses of variance (ANOVA) were performed using general linear models at $95 \%$ of confidence level. The graphs present the mean value of the measurements with an error bar representing the range of standard deviations.

\section{Results and Discussion}

Starch plants produce large amounts of wastewater. Treatment and disposal of this wastewater represents an extra cost for the industry. Recently, more strict regulations have led the sector to search for alternative methods to reduce the impacts on the environment as well as the costs (or even bring new incomes) to the business. In this work, the wastewater of a wheat-starch plant was investigated as the substrate for the cultivation of A. oryzae and R. oryzae. The microorganisms effectively used the nutrients of the agro-industrial residue, reducing the impact of the industrial emission while producing value-added bio products. In this section, the results of the characterization of the waste water, fungal growth on wastewater, and COD removal are presented and discussed.

\section{Starch Plant's Wastewater}

Three samples of wastewater from a wheat-starch plant were used in this study: ED1 (clarified liquid from the first decanter), ED2 (clarified liquid from the second decanter), and SS (the mixture of the solid-rich streams of both decanters). The composition on solids, ash, carbohydrates, lignin, and nitrogen were determined for the three samples (Table 1). ED 1, ED 2, and SS had a total of carbohydrates of $17.29 \pm 0.20,20.30 \pm 0.40$, and $93.30 \pm 4.72 \mathrm{~g} / \mathrm{L}$ respectively. Monomeric sugars, however, represented only a small fraction of this total (18\% in ED1, $15 \%$ in ED2, 
Table 1 Characterization of the wheat-starch industry's wastewater streams

\begin{tabular}{llll}
\hline & $\mathrm{ED} 1$ & $\mathrm{ED} 2$ & $\mathrm{SS}$ \\
\hline $\mathrm{pH}$ & 5.28 & 5.29 & 3.85 \\
Total Kjeldahl nitrogen & $1.25 \pm 0.06^{\mathrm{a}}$ & $1.34 \pm 0.32^{\mathrm{a}}$ & $1.40 \pm 0.04^{\mathrm{a}}$ \\
(g/L) & & & \\
Total solids (g/L) & $28.52 \pm 0.08^{\mathrm{a}}$ & $32.19 \pm 0.43^{\mathrm{b}}$ & $96.68 \pm 0.70^{\mathrm{c}}$ \\
Ashes (g/L) & $1.93 \pm 0.02^{\mathrm{a}}$ & $1.90 \pm 0.11^{\mathrm{ab}}$ & $1.80 \pm 0.03^{\mathrm{b}}$ \\
Suspended solids (g/L) & $3.70 \pm 0.11^{\mathrm{a}}$ & $6.78 \pm 0.02^{\mathrm{b}}$ & $71.79 \pm 0.14^{\mathrm{c}}$ \\
Glucan (mg/g) & $446 \pm 9^{\mathrm{a}}$ & $600 \pm 73^{\mathrm{ab}}$ & $857 \pm 90^{\mathrm{b}}$ \\
Starch (mg/g) & $53 \pm 4^{\mathrm{a}}$ & $361 \pm 2^{\mathrm{b}}$ & $771 \pm 6^{c}$ \\
Xylan (mg/g) & $103 \pm 49^{\mathrm{a}}$ & $31 \pm 0^{\mathrm{a}}$ & $65 \pm 19^{\mathrm{a}}$ \\
Galactan (mg/g) & $\mathrm{ND}$ & $\mathrm{ND}$ & $3 \pm 0^{\mathrm{a}}$ \\
Arabinan (mg/g) & $\mathrm{ND}$ & $\mathrm{ND}$ & $51 \pm 8^{\mathrm{a}}$ \\
Mannan (mg/g) & $\mathrm{ND}$ & $\mathrm{ND}$ & $\mathrm{ND}$ \\
Lignin (mg/g) & $102 \pm 7^{\mathrm{a}}$ & $76 \pm 18^{\mathrm{ab}}$ & $49 \pm 16^{\mathrm{b}}$ \\
Soluble solids (g/L) & $24.82 \pm 0.14^{\mathrm{a}}$ & $25.41 \pm 0.43^{\mathrm{a}}$ & $24.88 \pm 0.71^{\mathrm{a}}$ \\
Glucose (g/L) & $1.68 \pm 0.02^{\mathrm{a}}$ & $1.62 \pm 0.08^{\mathrm{a}}$ & $3.65 \pm 0.29^{\mathrm{b}}$ \\
Fructose (g/L) & $1.43 \pm 0.02^{\mathrm{a}}$ & $1.44 \pm 0.01^{\mathrm{a}}$ & $1.41 \pm 0.30^{\mathrm{a}}$ \\
Galactose (g/L) & $0.50 \pm 0.03^{\mathrm{a}}$ & $0.53 \pm 0.01^{\mathrm{a}}$ & $0.56 \pm 0.01^{\mathrm{a}}$ \\
Raffinose (g/L) & $0.24 \pm 0.08^{\mathrm{a}}$ & $0.04 \pm 0.03^{\mathrm{a}}$ & $\mathrm{ND}$ \\
Glucan (g/L) & $7.22 \pm 0.07^{\mathrm{a}}$ & $8.07 \pm 0.17^{\mathrm{b}}$ & $10.44 \pm 0.35^{\mathrm{c}}$ \\
Xylan (g/L) & $2.32 \pm 0.02^{\mathrm{a}}$ & $2.41 \pm 0.03^{\mathrm{a}}$ & $3.91 \pm 0.04^{\mathrm{b}}$ \\
Galactan (g/L) & $0.08 \pm 0.03^{\mathrm{a}}$ & $0.08 \pm 0.01^{\mathrm{a}}$ & $0.07 \pm 0.01^{\mathrm{a}}$ \\
Arabinan (g/L) & $1.75 \pm 0.07^{\mathrm{a}}$ & $1.81 \pm 0.04^{\mathrm{a}}$ & $3.19 \pm 0.04^{\mathrm{b}}$ \\
Mannan (g/L) & $0.04 \pm 0.01^{\mathrm{a}}$ & $0.02 \pm 0.00^{\mathrm{a}}$ & $\mathrm{ND}$ \\
Lactic acid (g/L) & $1.29 \pm 0.02^{\mathrm{a}}$ & $1.29 \pm 0.01^{\mathrm{a}}$ & $3.23 \pm 0.14^{\mathrm{b}}$ \\
Acetic acid (g/L) & $1.06 \pm 0.07^{\mathrm{a}}$ & $1.04 \pm 0.05^{\mathrm{a}}$ & $1.48 \pm 0.13^{\mathrm{b}}$ \\
Glycerol (g/L) & $0.23 \pm 0.02^{\mathrm{a}}$ & $0.24 \pm 0.01^{\mathrm{a}}$ & $0.59 \pm 0.00^{\mathrm{b}}$ \\
Ethanol (g/L) & $0.29 \pm 0.01^{\mathrm{a}}$ & $0.68 \pm 0.03^{\mathrm{b}}$ & $2.04 \pm 0.15^{\mathrm{c}}$ \\
\hline & $27.3 \pm 1.2^{\mathrm{a}}$ & $36.7 \pm 4.7^{\mathrm{a}}$ & $58.7 \pm 2.1^{\mathrm{b}}$ \\
\hline
\end{tabular}

Values in any line which are not followed by the same letter are significantly different $(p<0.05)$

$N D$ not detected

${ }^{1}$ Part of the measured glucans

and 5\% in SS). In the ED1 and ED2 samples, most of the carbohydrates were present in the soluble form. The concentration of soluble carbohydrates was in the same range for the three samples. On the other hand, in the SS sample, most of the carbohydrates were present in the insoluble form and approximately $60 \%$ of the carbohydrates in the SS were suspended starch. The results also revealed that the content of hexoses was higher than the pentoses, with only a small proportion of xylose and arabinose among the carbohydrates.

Nasr et al. [10] reported the wastewater of a maize starch plant containing $3.88 \mathrm{~g} / \mathrm{L}$ of carbohydrates, with less than $30 \%$ soluble, which represents a much more diluted effluent compared to the ones tested in this study. Jin et al. [20] worked with starch processing wastewater with insoluble carbohydrate content of $2.36-3.55 \mathrm{~g} / \mathrm{L}$. These values are in the same range as the content of the samples ED1 and ED2 (2.03 and $4.28 \mathrm{~g} / \mathrm{l}$, respectively).

Within 95\% of confidence level, the Total Kjeldahl nitrogen (TKN) concentrations of the three samples were not significantly different $(1.25-1.40 \mathrm{~g} / \mathrm{L})$. The COD of the SS sample $(58.7 \pm 2.1 \mathrm{~g} / \mathrm{L})$ was significantly $(95 \%$ confidence level) higher than those of ED1 and ED2 (27.3 \pm 1.2 and $36.7 \pm 4.7 \mathrm{~g} / \mathrm{L}$, respectively). Comparatively, a maize starch wastewater had a TKN content of $12.2 \mathrm{mg} / \mathrm{L}$ and a COD concentration of $4.39 \mathrm{~g} / \mathrm{L}$ [10]. The COD and the suspended solids concentrations of tapioca starch wastewater were determined as being in the range of 13.5-25.0 and $2.2-4.2 \mathrm{~g} / \mathrm{L}$, respectively [21]. Comparable values were found in this study for the ED1 wastewater.

Presence of some microbial metabolites such as ethanol, acetic acid, lactic acid, and glycerol was also detected in the tested side streams. This might be caused by the microbial activity in the wastewater since the effluent was not kept under sterile conditions in the facility. The high concentration of metabolites, like lactic acid, in the SS sample may also have contributed to the low $\mathrm{pH}$ of this sample (3.85).

\section{Cultivation of Filamentous Fungi on the Wastewaters}

Aspergillus oryzae and $R$. oryzae were cultivated in the three effluents of a wheat-starch plant. ED1 and ED2 were used with no $\mathrm{pH}$ adjustment. Cultivation of the fungi in SS was performed both with and without $\mathrm{pH}$ adjustment (5.5 and 3.85 , respectively). Samples were taken at $0,3,6,12$, and $24 \mathrm{~h}$, and analyzed. When growing A. oryzae in ED1, the lag phase of substrate consumption lasted only $3 \mathrm{~h}$ whereas, for $R$. oryzae, the same lag phase took $6 \mathrm{~h}$. This might represent a better capacity of the Aspergillus strain to adapt to the medium than the Rhizopus. Addition of cellulase and amyloglucosidase in the side stream increased the lag phase for both microorganisms, taking 6 and $12 \mathrm{~h}$ for $A$. oryzae and $R$. oryzae, respectively. The longer lag phase observed when the enzymes were added may have been a consequence of the presence of preservatives in the enzyme cocktails. When supplemented with enzymes, the initial glucose concentration increased to $10.37 \pm 0.47 \mathrm{~g} / \mathrm{L}$. From the characterization of this side stream, the maximum concentration of glucose which could be obtained from the complete hydrolysis of the glucans was $11.47 \mathrm{~g} / \mathrm{L}$. In all the cases, the glucose was consumed until its near depletion within $24 \mathrm{~h}$. The other sugars started being consumed after glucose. Moreover, $R$. oryzae cultivation yielded the highest ethanol and lactic acid concentration using ED1 $(2.19 \pm 0.23 \mathrm{~g} / \mathrm{L}$ and $5.85 \pm 0.82 \mathrm{~g} / \mathrm{L}$, respectively). The profile of metabolites during the cultivation of the ED1 sample is shown in Fig. 2.

The results of the cultivation in ED2 stream were similar to those obtained in ED1 for both microorganisms. The 
Fig. 2 Concentration profiles of glucose (cross), other sugars (filled square), ethanol (filled circle), and lactic acid (filled triangle) in ED1 medium using: a $A$. oryzae; $\mathbf{b}$ R. oryzae; $\mathbf{c}$. oryzae and enzyme supplementation; and $\mathbf{d} R$. oryzae with enzyme supplementation
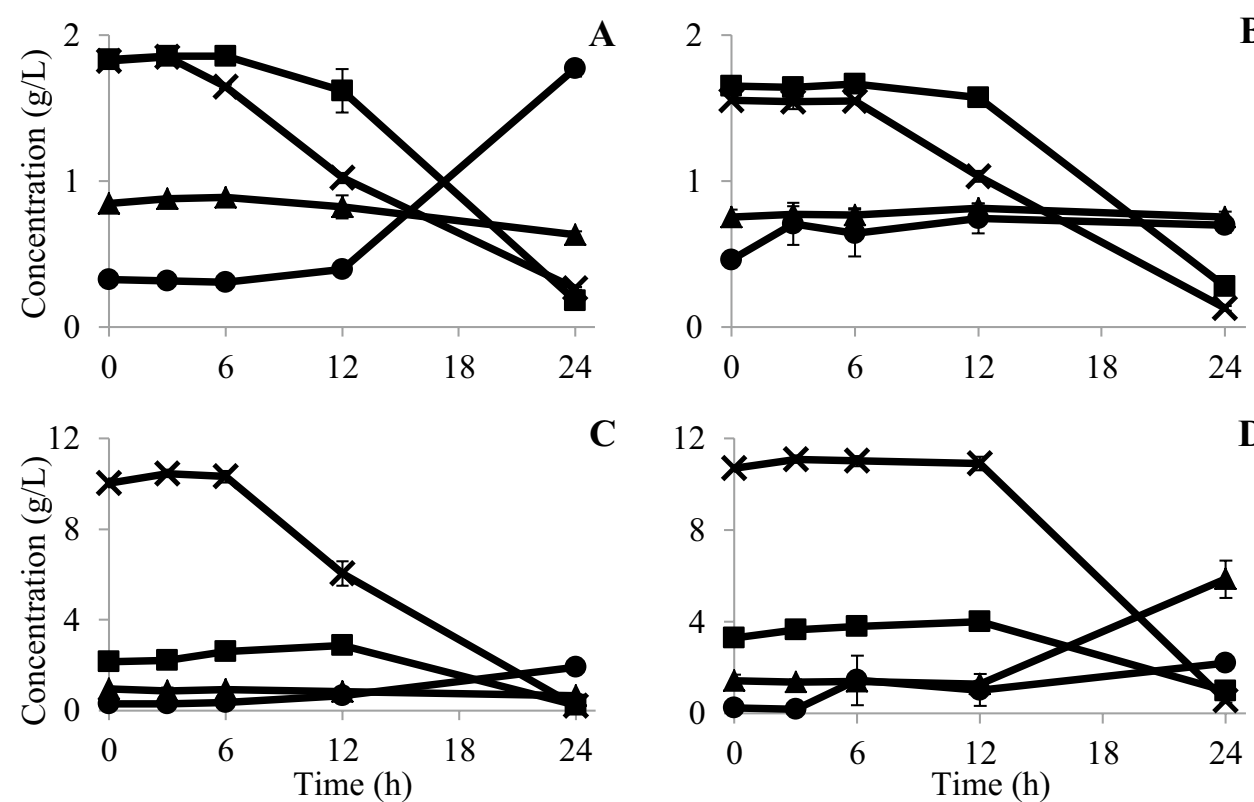

C

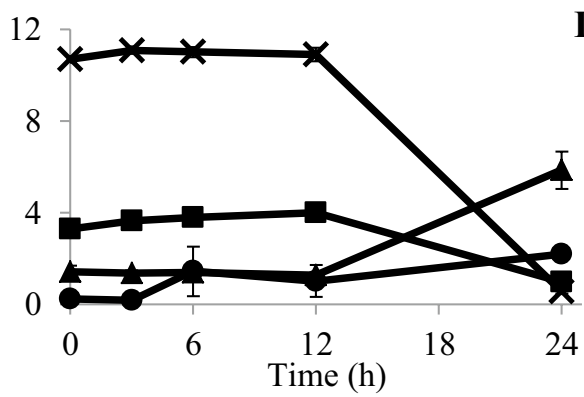

same trends for glucose consumption and ethanol production were observed (Fig. 3). Glucan content was significantly higher in ED2 compared to ED1. When enzymes were added in the ED2 medium, the glucose concentration reached values above $14 \mathrm{~g} / \mathrm{L}$. Ethanol and lactic acid maximum concentrations were obtained by cultivating $R$. oryzae with enzyme supplementation. In the ED2 medium, the final lactic acid concentration $(8.56 \pm 0.53 \mathrm{~g} / \mathrm{L})$ was significantly ( $95 \%$ confidence interval) higher than in the ED1 medium $(5.85 \pm 0.82 \mathrm{~g} / \mathrm{L})$. Considering the same confidence interval, the final ethanol concentration in the ED2 medium $(3.17 \pm 0.91 \mathrm{~g} / \mathrm{L}$, see Table 2$)$ was not different from the one obtained in ED1 stream $(2.19 \pm 0.23 \mathrm{~g} / \mathrm{L})$.
SS was examined in two conditions: at its original $\mathrm{pH}$ (3.85) and at $\mathrm{pH}$ 5.5. SS contained the highest amount of insoluble material among the three samples used in this work. Most of the insoluble fraction was composed of starch $(771 \mathrm{mg} / \mathrm{g})$. A. oryzae is a well-known $\alpha$-amylase enzyme producer [22]. The high amount of starch in the SS may have stimulated the production of this enzyme by the fungus. At pH 3.85, the rate of the hydrolysis of starch became higher than the uptake of glucose by the microorganism after $12 \mathrm{~h}$ (Fig. 4a), which led to an increase in concentration of this sugar. The low $\mathrm{pH}$ might have contributed to this phenomenon by decreasing the metabolic activity of the microorganism.
Fig. 3 Concentration profiles of glucose (cross), other sugars (filled square), ethanol (filled circle), and lactic acid (filled triangle) in ED2 medium using: a $A$. oryzae; b $R$. oryzae; $\mathbf{c} A$. oryzae with enzyme supplementation; and $\mathbf{d} R$. oryzae with enzyme supplementation

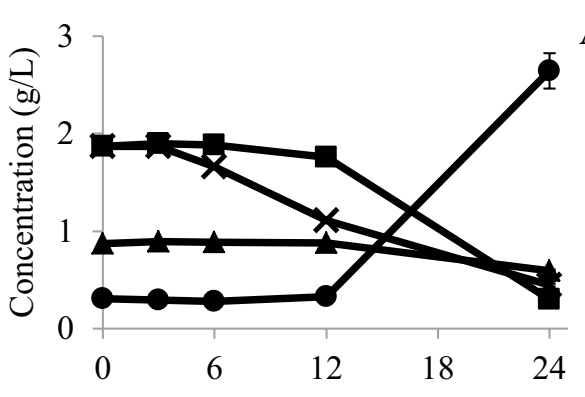

A 3

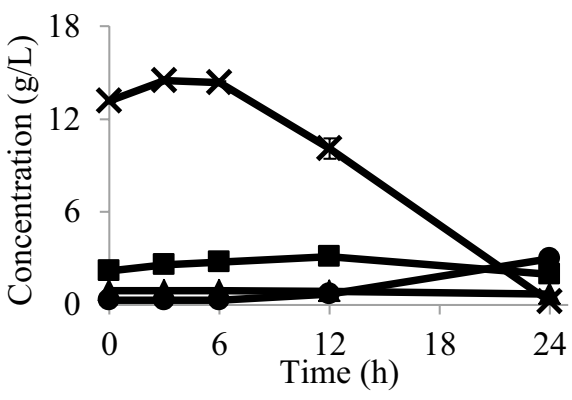

C 18
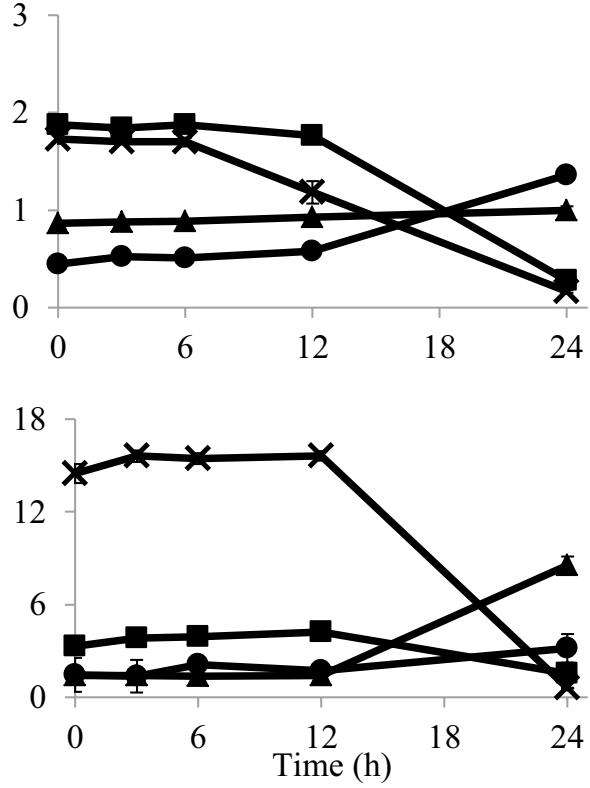
Table 2 Ethanol concentration at $24 \mathrm{~h}$ cultivation of the filamentous fungi in the ED1 and ED2 media

\begin{tabular}{llll}
\hline Medium & Microorganism & $\begin{array}{l}\text { Enzyme sup- } \\
\text { plementation }\end{array}$ & $\begin{array}{l}\text { Ethanol concentra- } \\
\text { tion at } 24 \mathrm{~h}(\mathrm{~g} / \mathrm{L})^{*}\end{array}$ \\
\hline ED1 & A. oryzae & No & $1.77 \pm 0.06^{\mathrm{a}}$ \\
& & Yes & $1.92 \pm 0.09^{\mathrm{a}}$ \\
& R. oryzae & No & $0.70 \pm 0.05^{\mathrm{b}}$ \\
& & Yes & $2.19 \pm 0.23^{\mathrm{ac}}$ \\
ED2 & A. oryzae & No & $2.65 \pm 0.18^{\mathrm{c}}$ \\
& & Yes & $2.97 \pm 0.17^{\mathrm{c}}$ \\
& R. oryzae & No & $1.36 \pm 0.04^{\mathrm{d}}$ \\
& & Yes & $3.17 \pm 0.91^{\mathrm{acd}}$ \\
\hline
\end{tabular}

*Values not followed by the same letter are significantly different $(p<0.05)$
The glucose concentration significantly ( $95 \%$ confidence level) increased during the first $6 \mathrm{~h}$ of cultivation of $R$. oryzae at both $\mathrm{pH}$ conditions. This result indicates the zygomycete, similarly to $A$. oryzae, produced and released enzymes in the medium to degrade the glucose oligomers. The enzyme activity, however, was not as intense as for the ascomycete strain, given that the glucose concentration did not increase as much and the hydrolysis rate did not overcome the glucose consumption by the microorganism after lag phase (Fig. 4b, d).

At $\mathrm{pH} 5.5$, A. oryzae was not able to fully consume the glucose in $24 \mathrm{~h}$ and $2.86 \pm 0.39 \mathrm{~g} / \mathrm{L}$ of glucose were left at the end of the cultivation (Fig. 4c). This may be because of production of amylolytic enzymes by the fungus, which kept hydrolyzing starch. Without enzyme supplementation,
Fig. 4 Concentration profiles of glucose (cross), other sugars (filled square), ethanol (filled circle), and lactic acid (filled triangle) in SS medium without enzyme supplementation using: a $A$. oryzae $(\mathrm{pH} 3.85)$; b $R$. oryzae $(\mathrm{pH} 3.85) ; \mathbf{c}$ A. oryzae $(\mathrm{pH}$ 5.5); $\mathbf{d}$ R. oryzae (pH 5.5); and with enzyme supplementation $\mathbf{e}$ A. oryzae ( $\mathrm{pH} 3.85) ; \mathbf{f}$. oryzae (pH 3.85); g A. oryzae (pH 5.5); h $R$. oryzae (pH 5.5)
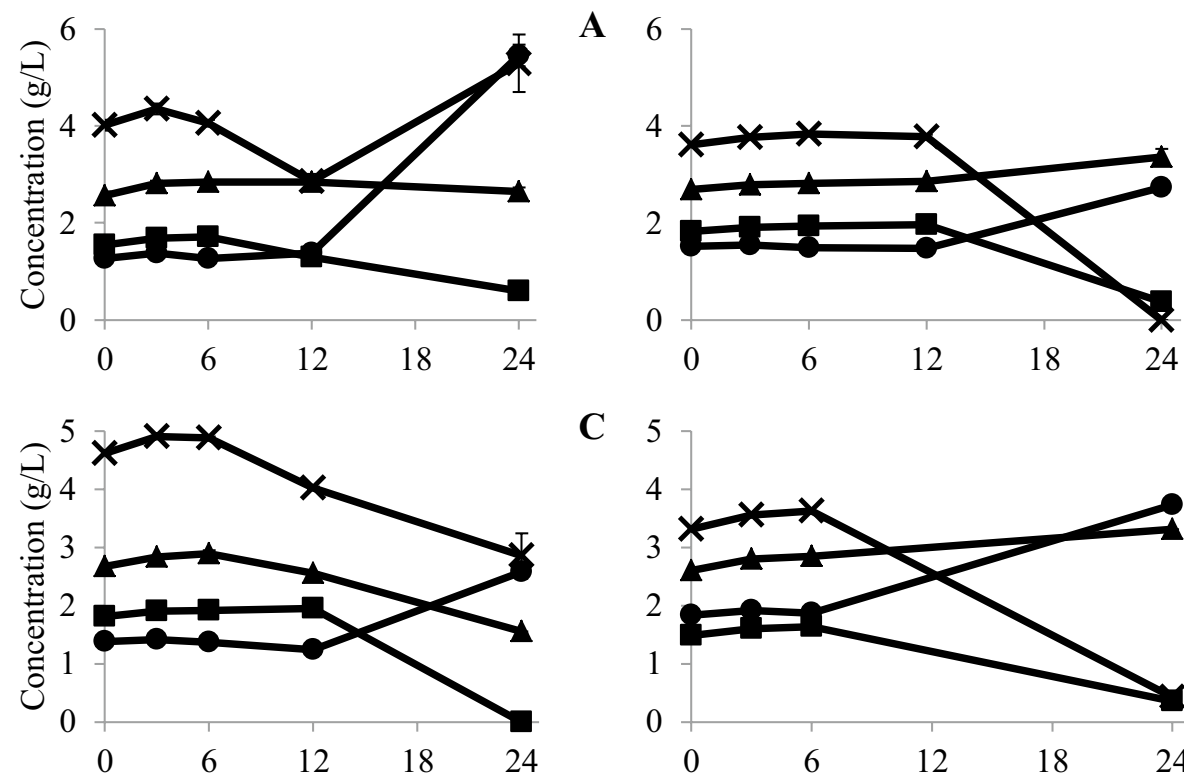

C 5
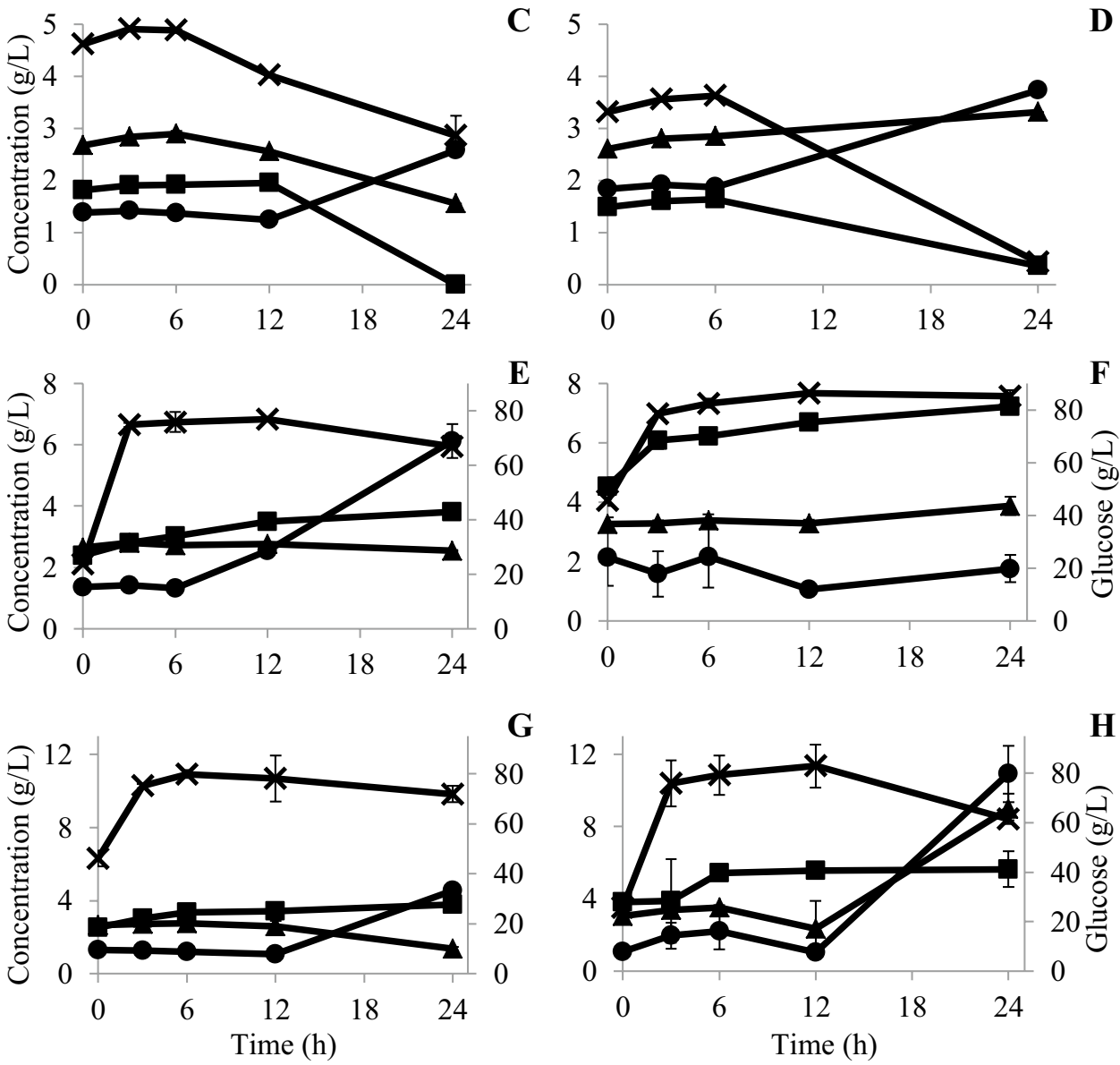

H

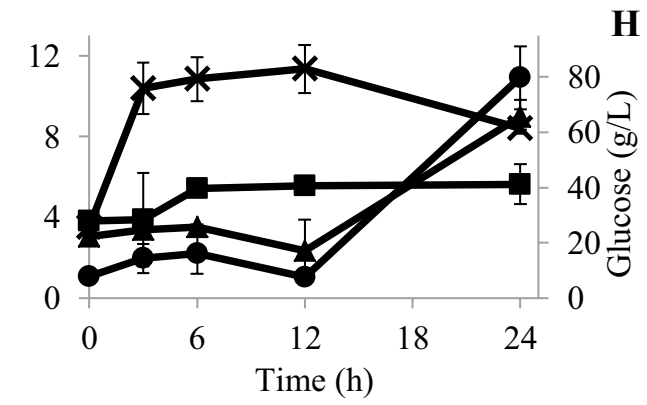


maximum ethanol concentration was obtained by $A$. oryzae $(5.45 \pm 0.22 \mathrm{~g} / \mathrm{L})$ when using SS at $\mathrm{pH} 3.85$.

When cellulase and amyloglucosidase were added to the SS medium, glucose concentration reached a maximum of $86.33 \pm 1.09 \mathrm{~g} / \mathrm{L} 12 \mathrm{~h}$ after the beginning of the cultivation of $R$. oryzae at pH 3.85 (Fig. 4f). The average value was slightly higher than the theoretical yield from the complete glucan hydrolysis of the SS sample $(83.61 \pm 0.49 \mathrm{~g} / \mathrm{L})$, although the values are not significantly different (95\% confidence interval). Moreover, during the cultivation, no significant productions of ethanol and lactic acid were detected, indicating no fungal activity. The high concentration of sugars combined with the low $\mathrm{pH}$ may have inhibited the growth of the strain. In the other cases which there was enzyme supplementation to the $\mathrm{pH}$-adjusted SS medium, a reduction was observed in the glucose concentration accompanied by the production of ethanol (both fungi) and lactic acid ( $R$. oryzae) at the last $12 \mathrm{~h}$ of the cultivation (Fig. $4 \mathrm{e}, \mathrm{g}, \mathrm{h}$ ). Most part of the glucose, however, remained in the medium. Additionally, for the same medium, although an upward trend was detected for the concentration of the sugars other than glucose, the difference was not significant considering a 95\% confidence interval.

Maximum ethanol concentration $(10.91 \pm 1.55 \mathrm{~g} / \mathrm{L})$ was obtained at $\mathrm{pH} 5.5$ when cultivating $R$. oryzae. This cultivation also resulted in the maximum glucose reduction (compared to the highest concentration achieved in the cultivation), yielding a $26 \%$ decrease in the glucose concentration.

\section{Fungal Biomass Production}

The biomass produced during cultivation was harvested and weighted. Protein content, as an important characteristic for making the biomass eligible for formulation of animal feed, was analyzed using the Kjeldahl method. Additional components of the fungal biomass may include lipids and structural carbohydrates (e.g. the chitosan and chitin present in R. oryzae cell wall) [15]. The results are presented in Table 3. The highest biomass production was achieved by growing $A$. oryzae in SS at pH $3.85(49.16 \pm 5.96 \mathrm{~g} / \mathrm{L})$ while the biomass with the highest protein content was the $R$. oryzae grown in the ED2 with enzyme supplementation $(50.76 \pm 0.71 \% \mathrm{w} / \mathrm{w})$. Although a very high amount of biomass was obtained using SS, the protein content was very low (below $17 \% \mathrm{w} / \mathrm{w}$ ). This may be explained by the high amount of suspended solids in the sample, and the capacity of the filamentous fungi to use the solids as a support to grow. The ability of filamentous fungi to improve the flocculation of activated sludge by the formation of a mycelial network has been previously reported [23]. These microorganisms reinforce the structure of the floc, resulting in larger and stronger flocs. The consequence is better sludge settling and low turbidity of the sewage effluent. Thus, it can be inferred that the suspended solids, with high content of carbohydrates, were wrapped by the fungal mycelium, resulting in a biomass with low concentration of proteins.

Jin et al. [24] reported a dry biomass production of $6.05 \mathrm{~g} / \mathrm{L}$ containing $36.58 \%$ protein from the cultivation of A. oryzae in an effluent of starch production from corn and

Table 3 Biomass concentration at the end of the cultivation and its respective protein concentration

\begin{tabular}{|c|c|c|c|c|c|}
\hline Medium & Microorganism & $\begin{array}{l}\text { Enzyme supple- } \\
\text { mentation }\end{array}$ & Dry biomass $(\mathrm{g} / \mathrm{L}) *$ & Protein $(\% \mathrm{w} / \mathrm{w})^{*}$ & Nitrogen recovery $(\%)^{*}$ \\
\hline \multirow[t]{4}{*}{ ED1 } & \multirow[t]{2}{*}{ A. oryzae } & No & $9.58 \pm 3.54^{\mathrm{ab}}$ & $36.38 \pm 0.75^{\mathrm{ab}}$ & $44.75 \pm 0.58^{\mathrm{ab}}$ \\
\hline & & Yes & $10.19 \pm 2.67^{\mathrm{ab}}$ & $36.70 \pm 0.85^{\mathrm{ab}}$ & $48.02 \pm 0.45^{\mathrm{cd}}$ \\
\hline & \multirow[t]{2}{*}{ R. oryzae } & No & $9.55 \pm 0.73^{\mathrm{a}}$ & $36.65 \pm 0.77^{\mathrm{ab}}$ & $44.94 \pm 0.17^{\mathrm{a}}$ \\
\hline & & Yes & $8.25 \pm 1.07^{\mathrm{a}}$ & $43.88 \pm 0.93^{\mathrm{c}}$ & $46.49 \pm 0.23^{\mathrm{e}}$ \\
\hline \multirow[t]{4}{*}{ ED2 } & \multirow[t]{2}{*}{ A. oryzae } & No & $14.39 \pm 2.75^{\mathrm{abc}}$ & $34.26 \pm 0.79^{a}$ & $58.69 \pm 0.46^{\mathrm{f}}$ \\
\hline & & Yes & $10.25 \pm 1.54^{\mathrm{ab}}$ & $38.72 \pm 1.29^{\mathrm{b}}$ & $47.25 \pm 0.33^{\text {cde }}$ \\
\hline & \multirow[t]{2}{*}{ R. oryzae } & No & $13.33 \pm 1.05^{\mathrm{b}}$ & $33.95 \pm 0.93^{\mathrm{a}}$ & $53.88 \pm 0.23^{g}$ \\
\hline & & Yes & $7.83 \pm 0.23^{\mathrm{a}}$ & $50.76 \pm 0.71^{\mathrm{d}}$ & $47.32 \pm 0.13^{\mathrm{ch}}$ \\
\hline \multirow[t]{4}{*}{$\mathrm{SS}(\mathrm{pH} 3.85)$} & \multirow[t]{2}{*}{ A. oryzae } & No & $49.16 \pm 5.96^{\mathrm{d}}$ & $11.21 \pm 0.31^{\mathrm{e}}$ & $62.98 \pm 0.95^{\mathrm{i}}$ \\
\hline & & Yes & $43.47 \pm 7.04^{\mathrm{de}}$ & $15.57 \pm 0.72^{\mathrm{fg}}$ & $77.35 \pm 1.13^{\mathrm{j}}$ \\
\hline & \multirow[t]{2}{*}{ R. oryzae } & No & $25.20 \pm 0.21^{\mathrm{f}}$ & $14.73 \pm 0.64^{\mathrm{fg}}$ & $42.42 \pm 0.11^{\mathrm{k}}$ \\
\hline & & Yes & $26.08 \pm 1.87^{\mathrm{ef}}$ & $14.70 \pm 0.62^{\mathrm{fg}}$ & $43.81 \pm 0.32^{\mathrm{b}}$ \\
\hline \multirow[t]{4}{*}{$\mathrm{SS}(\mathrm{pH} 5.5)$} & \multirow[t]{2}{*}{ A. oryzae } & No & $44.13 \pm 0.88^{\mathrm{d}}$ & $12.48 \pm 0.22^{\mathrm{h}}$ & $62.94 \pm 0.15^{\mathrm{i}}$ \\
\hline & & Yes & $32.56 \pm 6.45^{\text {cdef }}$ & $13.39 \pm 0.55^{\mathrm{fh}}$ & $49.83 \pm 1.04^{\mathrm{d}}$ \\
\hline & \multirow[t]{2}{*}{ R. oryzae } & No & $25.89 \pm 0.85^{\mathrm{f}}$ & $15.79 \pm 0.59^{\mathrm{g}}$ & $46.72 \pm 0.17^{\mathrm{eh}}$ \\
\hline & & Yes & $38.69 \pm 3.67^{\mathrm{d}}$ & $16.87 \pm 0.66^{\mathrm{g}}$ & $74.59 \pm 0.60^{j}$ \\
\hline
\end{tabular}

*Values in any column which are not followed by the same letter are significantly different $(p<0.05)$ 
wheat. These values are in agreement with the ones obtained for ED1 and ED2 samples in this paper. Cultivation of Rhizopus oligosporus in starch processing wastewater yielded around $5 \mathrm{~g} / \mathrm{L}$ of dry biomass [20] while less than $2 \mathrm{~g} / \mathrm{L}$ of $R$. arrhizhus dry biomass were obtained from the cultivation in wastewater of a potato chips plant (20-30 g COD/L) [25].

Within a $95 \%$ confidence level, $A$. oryzae and $R$. oryzae did not yield different biomass concentration when cultivated in the ED1 and ED2 samples when comparing the biomasses grown in the same sample and enzyme supplementation. All the values are in the range of 7.83-14.39 g/L. The biomass production average was superior for A. oryzae, but in most of the cases the protein content of the $R$. oryzae biomass was numerically superior. A. oryzae did, however, produce more biomass than $R$. oryzae when the fungi were grown in SS medium without enzyme supplementation (both $\mathrm{pH})$. This result might be explained by a more entangled growth of $A$. oryzae with the SS insoluble material compared to $R$. oryzae. A. oryzae might have had higher affinity with the solid material, growing more attached to it. This can also explain why A. oryzae was more efficient on degrading the glucans and releasing glucose in the medium. The biomass concentrations at the end of the fermentation, when enzymes were added to the SS medium, are not statistically different due to the large standard deviations obtained for both microorganisms. This is a typical problem when working with high solid content substrates due to the huge impact slight variations in factors e.g. agitation causes in the results.

For cultivation in the ED1 and the ED2 samples supplemented with enzymes, the collected biomass of $R$. oryzae contained significantly higher protein content than $A$. oryzae biomass (respectively for ED1 and ED2, 43.88 \pm 0.93 and $50.76 \pm 0.71$ for $R$. oryzae, and $36.70 \pm 0.85$ and $38.72 \pm 1.29$ for $A$. oryzae). This indicates $R$. oryzae was more efficient on converting the released sugars to proteins than $A$. oryzae. Without enzyme supplementation, both strains produced biomass with similar protein content. Moreover, addition of enzyme did not change the protein content of the Aspergillus biomass, and only $R$. oryzae effectively managed to convert the extra sugar into more protein. Protein content is an important factor to be considered if the biomass is intended to be used as animal feed.

Supplementation with amyloglucosidase and cellulose only resulted in higher biomass production for the cultivation of $R$. oryzae in ED2 and SS at pH 5.5 (compared to the cultivation without addition of enzymes). Similarly to the previous discussion, $R$. oryzae again demonstrated higher capacity to use the extra sugar and efficiently convert it to biomass.

Up to $77.35 \pm 1.13 \%$ of the nitrogen initially present in the $\mathrm{SS}$ is converted into biomass by $A$. oryzae when growing at $\mathrm{pH} 3.85$ and with addition of enzymes (see Table 3 ). At these same conditions, $R$. oryzae yielded the lowest nitrogen recovery $(42.42 \pm 0.11 \%)$. Maximum nitrogen recovery by $R$. oryzae was obtained when using the same stream (i.e. SS) but at higher $\mathrm{pH}$ (5.5). In this case, with the addition of the enzymes, the nitrogen recovery was $74.59 \pm 0.60 \%$.

\section{COD removal}

After 24 h cultivation, less than $60 \%$ and $50 \%$ of the COD of the ED1 and ED2 were removed by $A$. oryzae, respectively. In both cases, $A$. oryzae was more efficient than $R$. oryzae in removing COD of the samples. Cultivation of microorganisms in the SS wastewater did not result in a detectable removal of COD. In order to achieve a higher efficiency of COD removal, the cultivation was carried out for $72 \mathrm{~h}$ in all the samples, using $A$. oryzae and enzyme supplementation. The COD removal was determined to be $84.88 \pm 1.25$ and $84.33 \pm 3.6 \%$ for ED1 and ED2, respectively.

For the SS wastewater ( $\mathrm{pH} 3.85$ ), after the 72 h cultivation there was still no detected reduction in COD concentration. Further investigation was then carried out by monitoring the glucose concentration during the cultivation in the SS medium. The results are presented in Fig. 5, and show that, for A. oryzae, the lag phase lasted for $72 \mathrm{~h}$, and between 72 and $120 \mathrm{~h}$, the glucose concentration was reduced to $5.04 \pm 0.04 \mathrm{~g} / \mathrm{L}$. Ethanol started being produced after $72 \mathrm{~h}$, and reached $20.04 \pm 0.49 \mathrm{~g} / \mathrm{L}$ at $120 \mathrm{~h}$. This represents a very high concentration for an ethanol production plant. The $R$. oryzae cultivation followed a different profile, with the glucose being consumed between 24 and $72 \mathrm{~h}$, and the remaining glucose (approximately $35 \mathrm{~g} / \mathrm{L}$ ) not being further
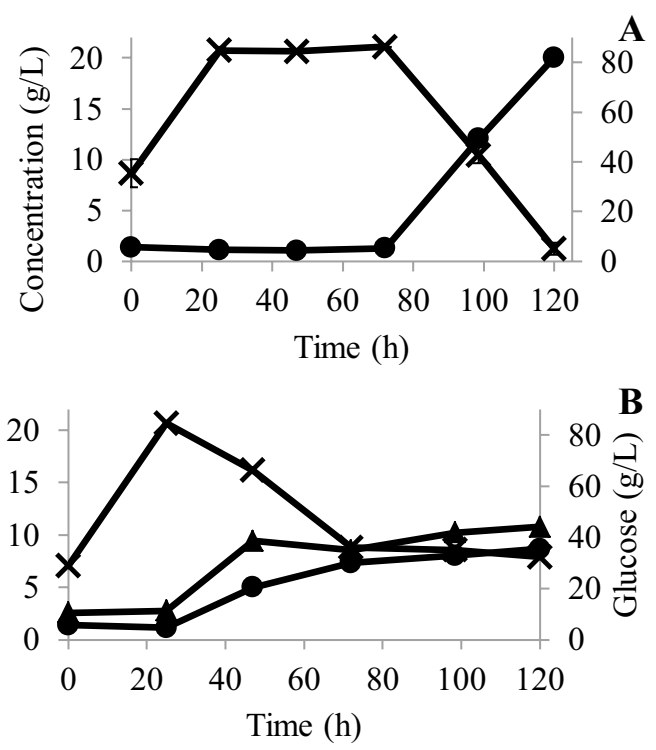

Fig. 5 Concentration profiles of glucose (cross), ethanol (filled circle) and lactic acid (filled triangle) from $\mathbf{a} A$. oryzae and $\mathbf{b} R$. oryzae cultivation in SS medium ( $\mathrm{pH} 3.85$ ) with enzyme supplementation 
consumed. Ethanol and lactic acid production followed the same trends; with little variations after $72 \mathrm{~h}$. High lactic acid concentration (above $10 \mathrm{~g} / \mathrm{L}$ ) may have inhibited fungal activity, and stopped the fermentation.

After 5 days, the COD of the SS sample treated with $A$. oryzae was $42.0 \mathrm{~g} / \mathrm{L}$, which represents a removal efficiency of only $28.4 \%$. The high residual COD is the result of the high ethanol production which might be the result of poor mass transfer in the SS medium, the last being a consequence of the high content of solids. The characteristics of the sample make it difficult for oxygen to be dissolved, creating an anaerobic environment. This leads to a high production of ethanol, explaining the high COD. However, even though the COD remains high, the considerable ethanol concentration in the fermented broth suggests purification of the alcohol can be a worthwhile strategy. Therefore, the stream should not be considered as a wastewater.

After 5 days, $11.95 \pm 0.46 \mathrm{~g} / \mathrm{L}$ of dry A. oryzae biomass and $22.69 \pm 1.93 \mathrm{~g} / \mathrm{L}$ of dry $R$. oryzae biomass were obtained in the SS sample. The result for $R$. oryzae is similar to the one obtained for $24 \mathrm{~h}$ cultivation. The lower amount of biomass of the ascomycete compared to the $24 \mathrm{~h}$ experiment, however, may have been caused by the degradation of the fibers used as support for the growth of the microorganisms (The insoluble carbohydrates which were entrapped inside the fungal biomass). The higher content of protein in the biomass supports this conclusion $(35.72 \pm 1.24 \% \mathrm{w} / \mathrm{w})$.

\section{Industrial Perspectives for the Wastewater Treatment by Filamentous Fungi}

Further investigation on the production of ethanol and organic acids using this wastewater seems to be promising. This would lead to a larger portfolio of products from the residue using the same microorganism, creating a flexible process which can be operated according to market demands. Currently, the studied wastewater is sent to the municipal wastewater treatment plant, which results in extra costs for the industrial facility. Mahboubi et al. [26] have highlighted how wastes can contribute to the income of a company and avoid the high cost related to the wastewater treatment. The production of ethanol, for instance, can be studied as part of an integrated process, in which the obtained broth can be filtered for the collection of the fungal biomass and the liquid fraction can be processed for purification of ethanol. Since the solid fraction of the streams was found to be rich in carbohydrates and easily hydrolyzed, the three streams can be mixed together for cultivation of A. oryzae, yielding fungal biomass and ethanol. Such scenario would work as a last step for the treatment of the wastewater. The clarified ethanol-free effluent can even be partially recycled to the beginning of the process.

\section{Conclusions}

The effluent of a wheat-starch plant was treated by A. oryzae and $R$. oryzae. These fungi can convert the organic material to protein sources for e.g. animal feed. A large amount of carbohydrates was identified in all the wastewater streams (ED1, ED2, and SS). The microorganisms consumed the sugars and hydrolyzed the long-chain carbohydrates in the wastewater, and produced a protein-rich biomass. A. oryzae showed high capacity to hydrolyze starch although a long lag phase was found when it was cultivated in a high sugarconcentration medium. More than $80 \%$ of the initial COD of the clarified streams were consumed by the microorganisms. The high concentration of ethanol obtained in the solid-rich sample represents an opportunity to produce another product from the same treatment process.

Acknowledgements This work was financed by the Coordination for the Improvement of Higher Education Personnel (CAPES-Brazil) and Procon AB (Sweden) in collaboration with Interstarch $\mathrm{GmbH}$.

Open Access This article is distributed under the terms of the Creative Commons Attribution 4.0 International License (http://creativeco mmons.org/licenses/by/4.0/), which permits unrestricted use, distribution, and reproduction in any medium, provided you give appropriate credit to the original author(s) and the source, provide a link to the Creative Commons license, and indicate if changes were made.

\section{References}

1. FAO: Save and Grow in Practice: Maize, Rice, Wheat: A Guide to Sustainable Cereal Production. FAQ, Rome, 2016

2. Fava, F., Zanaroli, G., Vannini, L., Guerzoni, E., Bordoni, A., Viaggi, D., Robertson, J., Waldron, K., Bald, C., Esturo, A., Talens, C., Tueros, I., Cebrian, M., Sebök, A., Kuti, T., Broeze, J., Macias, M., Brendle, H.-G.: New advances in the integrated management of food processing by-products in Europe: sustainable exploitation of fruit and cereal processing by-products with the production of new food products (NAMASTE EU). New Biotechnol. 30(6), 647-655 (2013)

3. Starch.eu (2017) http://www.starch.eu/ Accessed 20 Oct 2017

4. Radley, J.A.: Industrial Uses of Starch and its Derivatives, 1st edn. Applied Science Publishers LTD, Essex (1976)

5. Ahmadi-Abhari, S., Woortman, A.J.J., Hamer, R.J., Loos, K.: Rheological properties of wheat starch influenced by amyloselysophosphatidylcholine complexation at different gelation phases. Carbohyd. Polym. 122, 197-201 (2015)

6. Van Der Borght, A., Goesaert, H., Veraverbeke, W.S., Delcour, J.A.: Fractionation of wheat and wheat flour into starch and gluten: overview of the main processes and the factors involved. J. Cereal Sci. 41(3), 221-237 (2005)

7. Pu, S.-Y., Qin, L.-L., Che, J.-P., Zhang, B.-R., Xu, M.: Preparation and application of a novel bioflocculant by two strains of Rhizopus sp. using potato starch wastewater as nutrilite. Bioresour. Technol. 162, 184-191 (2014)

8. Yu, D., Li, C., Wang, L., Zhang, J., Liu, J., Wei, Y.: Multiple effects of trace elements on methanogenesis in a two-phase 
anaerobic membrane bioreactor treating starch wastewater. Appl. Microbiol. Biotechnol. 100, 1-12 (2016)

9. Deng, S., Bai, R., Hu, X., Luo, Q.: Characteristics of a bioflocculant produced by Bacillus mucilaginosus and its use in starch wastewater treatment. App. Microbiol. Biotechnol. 60(5), 588593 (2003)

10. Nasr, M., Tawfik, A., Suzuki, M., Ookawara, S.: Mathematical modeling of bio-hydrogen production from starch wastewater via up-flow anaerobic staged reactor. Desalin. Water Treat. 54(1), 50-58 (2015)

11. Bachmann, T.M., van der Kamp, J.: Environmental cost-benefit analysis and the EU (European Union) industrial emissions directive: exploring the societal efficiency of a DeNOx retrofit at a coal-fired power plant. Energy 68, 125-139 (2014)

12. Ferreira, J.A., Mahboubi, A., Lennartsson, P.R., Taherzadeh, M.J.: Waste biorefineries using filamentous Ascomycetes fungi: present status and future prospects. Bioresour. Technol. 215, 334-345 (2016)

13. Nair, R.B., Taherzadeh, M.J.: Valorization of sugar-to-ethanol process waste vinasse: a novel biorefinery approach using edible Ascomycetes filamentous fungi. Bioresour. Technol. 221, 469$476(2016)$

14. Moustogianni, A., Bellou, S., Triantaphyllidou, I.E., Aggelis, G.: Feasibility of raw glycerol conversion into single cell oil by zygomycetes under non-aseptic conditions. Biotechnol. Bioeng. 112(4), 827-831 (2015)

15. Ferreira, J.A., Lennartsson, P.R., Edebo, L., Taherzadeh, M.J.: Zygomycetes-based biorefinery: present status and future prospects. Bioresour. Technol. 135, 523-532 (2013)

16. Jin, B., van Leeuwen, J.H., Yu, Q., Patel, B.: Screening and selection of microfungi for microbial biomass protein production and water reclamation from starch processing wastewater. J. Chem. Technol. Biotechnol. 74(2), 106-110 (1999)

17. Sluiter, A., Hames, B., Ruiz, R., Scarlata, C., Sluiter, J., Templeton, D., Crocker, D.: Determination of Structural Carbohydrates and Lignin in Biomass. National Renewable Energy Laboratory, Golden (2008)

18. Sluiter, A., Hames, B., Ruiz, R., Scarlata, C., Sluiter, J., Templeton, D.: Determination of Sugars, Byproducts, and Degradation Products in Liquid Fraction Process Samples. National Renewable Energy Laboratory, Golden (2006)

19. Souza Filho, P.F., Zamani, A., Taherzadeh, M.J.: Production of edible fungi from potato protein liquor (PPL) in airlift bioreactor. Fermentation 3, 12 (2017)

20. Jin, B., van Leeuwen, H.J., Patel, B., Doelle, H.W., Yu, Q.: Production of fungal protein and glucoamylase by Rhizopus oligosporus from starch processing wastewater. Process Biochem. 34(1), 59-65 (1999)

21. Annachhatre, A.P., Amatya, P.L.: UASB treatment of tapioca starch wastewater. J. Environ. Eng. 126(12), 1149-1152 (2000)

22. Francis, F., Sabu, A., Nampoothiri, K.M., Ramachandran, S., Ghosh, S., Szakacs, G., Pandey, A.: Use of response surface methodology for optimizing process parameters for the production of $\alpha$-amylase by Aspergillus oryzae. Biochem. Eng. J. 15(2), $107-115$ (2003)

23. Murugesan, K., Selvam, A., Wong, J.W.C.: Flocculation and dewaterability of chemically enhanced primary treatment sludge by bioaugmentation with filamentous fungi. Bioresour. Technol. 168, 198-203 (2014)

24. Jin, B., van Leeuwen, H.J., Patel, B., Yu, Q.: Utilisation of starch processing wastewater for production of microbial biomass protein and fungal $\alpha$-amylase by Aspergillus oryzae. Bioresour. Technol. 66(3), 201-206 (1998)

25. Huang, L.P., Dong, T., Chen, J.W., Li, N.: Biotechnological production of lactic acid integrated with fishmeal wastewater treatment by Rhizopus oryzae. Bioprocess Biosyst. Eng. 30(2), 135-140 (2007)

26. Mahboubi, A., Ferreira, J.A., Taherzadeh, M.J., Lennartsson, P.R.: Value-added products from dairy waste using edible fungi. Waste Manag. 59, 518-525 (2017) 